Vol. 2, No. 1, 2020

https://doi.org/10.23939/jtbp2020.01.038

Orest Voznyak ${ }^{1}$, Mariusz Adamski ${ }^{2}$, Peter Kapalo ${ }^{3}$, Oleksandr Dovbush ${ }^{1}$, Iryna Sukholova ${ }^{1}$

\title{
INVESTIGATION OF THE RETURN FLOW AT THE AIR DISTRIBUTION BY SWIRL AND FLAT LAYING AIR JETS IN SMALL-SIZED PREMISES
}

\author{
${ }^{1}$ LvivPolytechnicNationalUniversity, \\ ${ }^{2}$ Politechnika Białostocka, \\ ${ }^{3}$ Technical University of Košice, \\ orest.voznyak@i.ua
}

(C) Voznyak O., Adamski M., Kapalo P., Dovbush O., Sukholova I., 2020

In this article the results of return flow at air distribution by flat laying jets experimental investigations are presented. The chart is composed, analytic equations are also obtained. By these results high efficiency of proposed air distribution scheme using in technological small-sized rooms is shown. The purpose of the work is to study the nature of the propagation of the swirl and flat flooring jets in a limited space of a production space of low height with the presence of technological equipment and maintenance personnel in it, to identify the patterns of development of the air tidal stream in the reverse flow and to justify the calculation methodology. The quantitative description of the characteristics and regularities of the development of the swirl and flat flooring compressed jets in the reverse flow is established. Calculation dependences were obtained for determining the parameters of the swirl and flat flooring compressed jets in the reverse flow. It is substantiated that the efficiency of the application of the swirl and flat flooring jets to supply air to the working area of the technological premises is high. The obtained results allow us to calculate the initial velocity of the swirl and tidal flat flooring compressed stream in a small-sized production rooms with the presence of technological equipment and service personnel and to determine the geometric parameters of the air distribution device. Application of air distribution with the use of the swirl and flat air jet laying effect allows to significantly increase the Air Distribution Performance Index criteria when supplying a big amount of air to the technological premises and thereby reducing the material consumption of the ventilation system.

Key words: air distribution, ventilation, flow rate, air velocity, swirl air jet, compressed stream, tidal flat air jet.

\section{Introduction}

As it is known, the physical state of the air environment in technological premises is characterized by parameters such as temperature, moisture content, air velocity, noise, dust, odors (Bin Zhao et al., 2003; Holyoake, 2006), $\mathrm{CO}_{2}$ concentration (Kapalo et al., 2018; Kapalo et al., 2019; Kapalo \& Siroczki, 2014; Kapalo et al., 2014) etc. Normalized parameters of internal air should be provided in the working (service) area of such premises, since the fact that the sanitaryhygienic parameters of the microclimate of the technological premises correspond to the physiological needs of a person depends, to a large extent, on its health and efficiency. The conditions of comfort are primarily determined by the air temperature and velocity. These values are supported by means of ventilation equipment and depend on the accepted organization of air exchange and air distribution schemes. In this case, the working area is located both in the forward 
and in the reverse (return) flow of the inflow stream. The combination of these factors determines the nature of the air flow and the development of ventilation jets in the room. (Chen \& Srebric, 2001; Kapalo et al., 2018).

\section{Target of this article}

This article is intended for studying the nature of the propagation of the swirl and flat flooring jets in a limited space of a production space of low height with the presence of technological equipment and maintenance personnel in it, to identify the patterns of development of the air tidal stream in the reverse flow and to justify the calculation methodology.

\section{Techniques used}

The importance of taking into account the influence of air flow disturbances, in connection with the presence of technological equipment and maintenance personnel in the room on air velocity distribution and their features, is investigated in (Gumen et al., 2016; Dovhaliuk \&Mileikovskyi, 2007; Dovhaliuk \&Mileikovskyi, 2008). In such conditions it is necessary to provide a sufficiently range of the flow. One of the means of increasing its range is the use of the Coanda effect, that is, the laying of a stream on the interior surfaces of walls or ceilings (Voznyak et al., 2019). In addition to increasing the range fertility, the phenomenon of laying a stream on the ceiling influences the flow of field, the expanded stream, the processes of mixing and extinction of velocity in the jet. Therefore, the most rational scheme of air distribution in the case of the presence of process equipment and maintenance staff in a production space of low height is the application of a method of supplying air to the working area by laying jets. It is advisable to propose the use of air distributors with a high intensity of extinguishing the velocity and temperature of the inflow air, that is, devices that provide an intense mixing of the tidal air with the surrounding (Dovhaliuk \& Mileikovskyi, 2013; Kapalo et al., 2017).

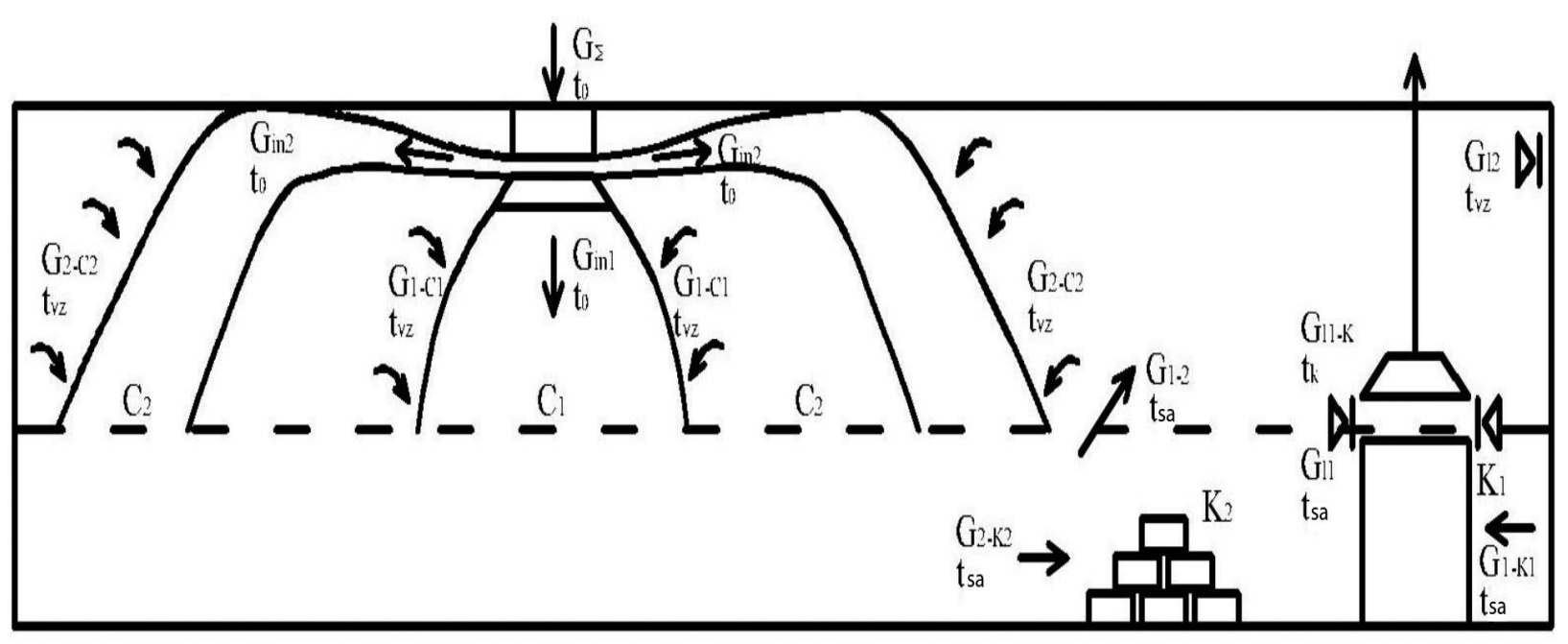

Fig. 1. Scheme of the swirl and flat laying air jet at stressed conditions of the small-sized production premise

Today, there are a large number of different designs of air distributors and circuits of distribution of inflow air, both in the upper and in the working area of premises (Kapalo et al., 2014; Srebric \& Chen, 2002), where the effect of laying the jets on the interior surfaces of walls or ceilings, which is a fairly widespread phenomenon in ventilation technology. 
In this paper, a concentrated inflow is oblique on the inner surface of the ceiling by flat cooled jets. The air distributor is located under the ceiling (Fig. 1) and creates the swirl and flat laying air jets (Voznyak et al., 2005).

A characteristic feature of such an air distribution scheme is a certain limitation of space for the development of direct and reverse flow of airflow walls, ceiling and floor of the room, as well as technological equipment and service personnel, which creates the so-called "compression" of the inflow stream. The air flow, moving in the confined space of this room, that is, in "compressed" conditions, forms a flat compressed jet and enters the service area.

In this work, a flat flooring air jet is considered, which is directed along a production room of low height in the presence of technological equipment and maintenance staff for a dead-end scheme, in which the exhaust hole is located in the same plane as the inflow one (Fig. 1). In this case, the serviced area where people are located, is washed by an induced jet by the return flow. In this connection, the issue of determining the patterns of air flow in the reverse flow becomes of great importance. The main attention in this work is devoted precisely to the study of the order of the development of air tidal stream in the reverse flow.

Since modern studies are based on the detection of empirical laws of jet flows (Grimitlin, 2004), this method was used in this paper. Experimental studies were carried out in the field at the stand, the scheme of which is presented in Fig. 1 under the following conditions and simplifications:

- a flat stream is isothermal;

- coefficient of extinguishing of the velocity of the flat inflow nozzles was $m=2.5$;

- the width of the slit hole was varied and equals: $l_{o}=300 \mathrm{~mm} ; l_{o}=450 \mathrm{~mm} ; l_{o}=600 \mathrm{~mm}$;

- the height of the crack was variable, namely: $b_{o}=20 \mathrm{~mm} ; b_{o}=30 \mathrm{~mm} ; b_{o}=40 \mathrm{~mm}$;

- air flow rate $L$, was variable and equals: $L_{1}=900 \mathrm{~m}^{3} /$ hour; $L_{2}=700 \mathrm{~m}^{3} /$ hour; $L_{3}=500 \mathrm{~m}^{3} /$ hour; $L_{4}=300 \mathrm{~m}^{3} /$ hour;

- the initial air velocity at the outflow from the inflow nozzle was within the limits: $V_{o}=5-15 \mathrm{~m} / \mathrm{s}$;

- the velocity of air in the reverse flow was considered at the mark $h=1,5 \mathrm{~m}$ and was presented in dimensionless form $\bar{V}=V_{r} / V_{o}$;

- value $\bar{V}$ depends from two dimensionless coordinates $\bar{x}=x / l$ and $\bar{y}=\left(y-y_{\lim }\right) /\left(B-y_{\lim }\right)$, where $x$ and $y$ are respectively longitudinal and transverse running coordinates, $\mathrm{m} ; l$ is the length of the room, $\mathrm{m} ; B$ and $y_{\text {lim }}$ are respectively half width of the room and the stream in the direct flow, $\mathrm{m}$;

- the points near the wall, which are not located in the boundary layer, were conventionally considered as coordinate $\bar{y}=1$.

The air velocity and temperature were measured by the thermal electrical anemometer Testo- 405 . Measurement of the air velocities at the settlement points was carried out using a coordinator with a grid of points $5 \times 5 \mathrm{~cm}$ in five cross-sections. In the course of experimental studies, the boundaries of the inflow stream in the zone of its direct and reverse flow were determined.

Based on experimental studies on the distribution of air in the rooms, we present the dimensionless velocities of air flow in the reverse flow in tabular form (Table 1), as well as in the form of chart (Fig. 2), that is, represent a two-factor functional dependence $\bar{V}=f(\bar{x} ; \bar{y})$, where $\bar{V}=V_{r} / V_{o}$.

Fig. 2 shows a graphical dependence $\bar{V}=f(\bar{x} ; \bar{y})$ according to experimental real research of the dimensionless velocity change in the reverse flow during the development of a flat laying compressed air jet in the small-sized technological premises. 
Dimensionless velocities in reverse flow $\bar{V}\left(\times 10^{-3}\right)$

\begin{tabular}{|c|c|c|c|c|c|c|}
\hline $\bar{x}$ & 0 & 0.2 & 0.4 & 0.6 & 0.8 & 1.0 \\
\hline \hline 0 & 13 & 17 & 25 & 40 & 30 & 18 \\
\hline 0.25 & 20 & 30 & 42 & 55 & 45 & 30 \\
\hline 0.5 & 10 & 12 & 15 & 20 & 18 & 15 \\
\hline 0.75 & 8 & 10 & 12 & 15 & 13 & 12 \\
\hline 1.0 & 7 & 8 & 10 & 12 & 11 & 10 \\
\hline
\end{tabular}

The graph (Fig. 2) is expediently approximated by polynomial dependence (1):

$$
\bar{V}=\sum_{i=o}^{m} \cdot \sum_{j=o}^{n} a_{i j} \cdot \bar{y}^{j} \cdot \bar{x}^{i}
$$

which is expressed in this way:

$$
\begin{aligned}
\bar{V}=(10.22+ & 21.45 \bar{y}-35.28 \bar{y}^{2}+\left(88.64+13.46 \bar{y}-159.68 \bar{y}^{2}\right) \cdot \bar{x}- \\
& \left.-\left(76.41+5.62 \bar{y}-133.92 \bar{y}^{2}\right) \cdot \bar{x}^{2}\right) \cdot 10^{-3}
\end{aligned}
$$

It should be noted that in order to determine the initial velocity $V_{o}$ it is necessary to know the value of the maximum velocity in the reverse flow $\bar{V}_{\max }$. To do this, in turn, it is needed to investigate $\bar{V}$ - function on the extremum, the necessary conditions of which are: if the function $\bar{V}=\mathrm{f}(\overline{\mathrm{x}}, \overline{\mathrm{y}})$ reaches the extremum at $\bar{x}=\bar{x}_{o}, \bar{y}=\bar{y}_{o}$, then every partial derivative of the first order from $\bar{V}$ becomes zero at these values of arguments. Differentiate in partial derivatives:

$$
\begin{aligned}
& \frac{\partial \bar{V}}{\partial \bar{x}}=\left(88.64+13.46 \bar{y}-159.68 \bar{y}^{2}-152.82 \bar{x}-11.24 \bar{y} \bar{x}+267.84 \bar{y}^{2} \bar{x}\right) \cdot 10^{-3} \\
& \frac{\partial \bar{V}}{\partial \bar{y}}=\left(21.45+13.46 \bar{x}-5.62 \bar{x}^{2}-70.56 \bar{y}-319.36 \bar{x} \bar{y}+267.84 \bar{x}^{-2} \bar{y}\right) \cdot 10^{-3}
\end{aligned}
$$

We obtain a system of two equations with two unknown values (5):

$$
\left\{\begin{array}{l}
\frac{\partial \bar{V}}{\partial \bar{x}}=0 \\
\frac{\partial \bar{V}}{\partial \bar{y}}=0
\end{array}\right.
$$

Solving the system of equations (5), we find the required values of $\bar{x}_{o}, \bar{y}_{o}$ on a certain segment of these arguments, respectively $\left[\bar{x}_{1} ; \bar{x}_{2}\right],\left[\bar{y}_{1} ; \bar{y}_{2}\right]$. Consequently, as a result of the calculations we obtain the coordinates of the stationary point $\mathrm{M}\left(\bar{x}_{o}, \bar{y}_{o}\right): \bar{x}_{o}=0.585$ and $\bar{y}_{o}=0.165$. 


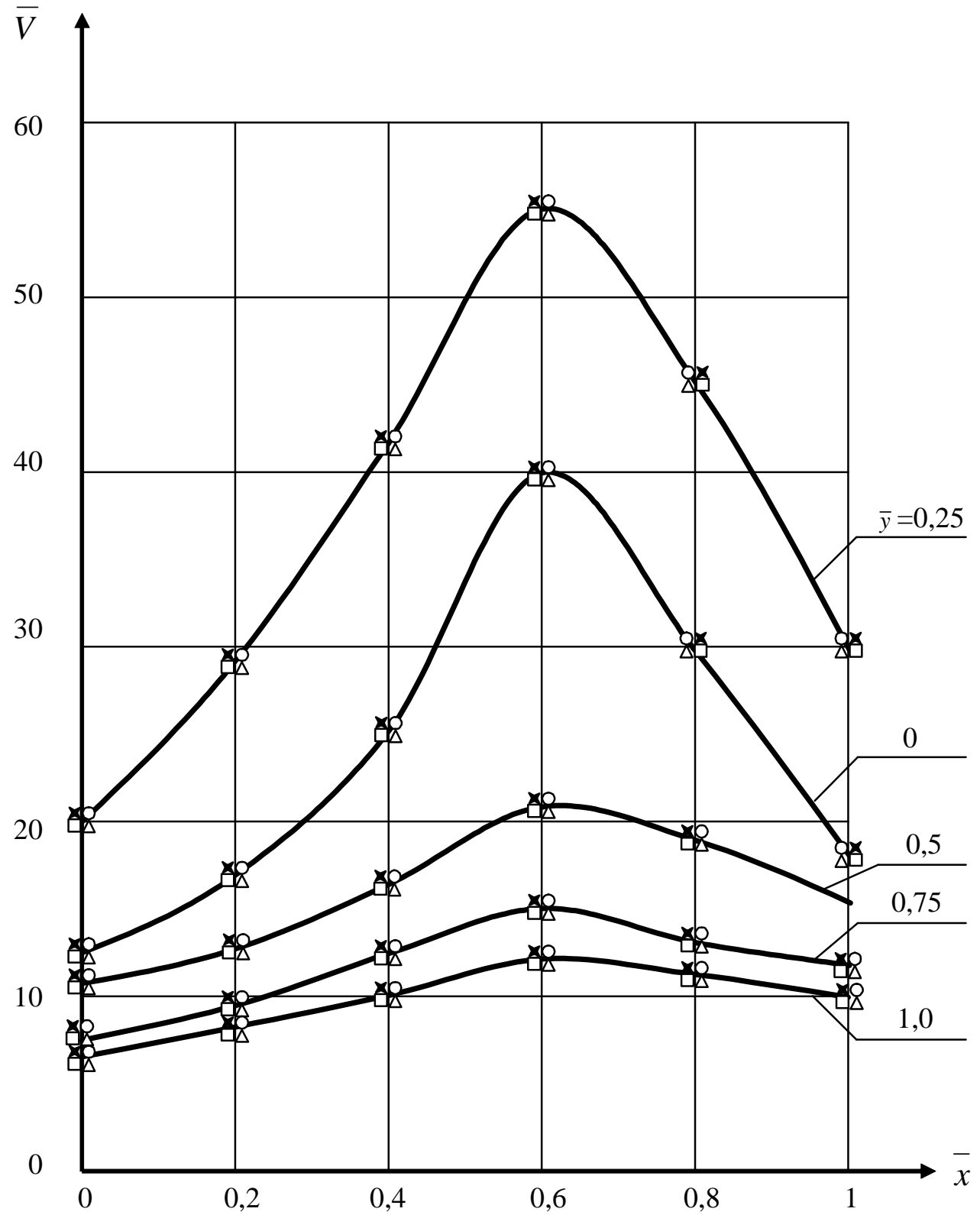

Fig. 2. Chart for determining the dimensionless velocities in the reverse air flow

Since there is no prior assurance of the existence of $\bar{V}$-function maximum, therefore, an additional study is needed, that is, it is necessary to establish sufficient conditions for the extremum. If $\bar{V}$ - function will have in some environment of point $\mathrm{M}\left(\bar{x}_{o}, \bar{y}_{o}\right)$ continuous second partial derivatives and if at this point the necessary conditions are fulfilled, then in the case when the second differential

$$
\partial^{2} \bar{V}=\sum_{i=1}^{2} \cdot \sum_{j=1}^{2} \cdot \frac{\partial^{2} \bar{V}}{\partial x_{i} \partial y_{j}} \mid\left(\bar{x}_{o}, \bar{y}_{o}\right)^{\Delta x_{i} \Delta y_{j}}
$$

is a positively defined quadratic form, then the function $\overline{\mathrm{V}}(\bar{x}, \bar{y})$ has a maximum at this point. In the case of these conditions, the $\bar{V}$ - function will have a stationary value at the point $\mathrm{M}\left(\bar{x}_{o}, \bar{y}_{o}\right)$, and the point $M$ itself will be called stationary. 
We investigate the positive definiteness of the quadratic form (7):

$$
\left(\begin{array}{ll}
\frac{\partial^{2} \bar{V}}{\partial \bar{x}} & \frac{\partial^{2} \bar{V}}{\partial \bar{x} \partial \bar{y}} \\
\frac{\partial^{2} \bar{V}}{\partial \bar{y} \partial \bar{x}} & \frac{\partial^{2} \bar{V}}{\partial \bar{y}^{2}}
\end{array}\right)
$$

It is advisable to enter the following notations:

$$
\frac{\partial^{2} \bar{V}}{\partial \bar{x}}=A ; \quad \frac{\partial^{2} \bar{V}}{\partial \bar{y}^{-2}}=B ; \quad \frac{\partial^{2} \bar{V}}{\partial \bar{x} \partial \bar{y}}=C
$$

Taking into account the property of the order of differentiation in partial derivatives:

$$
\frac{\partial^{2} z}{\partial x \partial y}=\frac{\partial^{2} z}{\partial y \partial x}
$$

the differential determinant Jacobian $(J)$ will look like:

$$
J=\left|\begin{array}{ll}
A & C \\
C & B
\end{array}\right|
$$

after disclosure we receive:

$$
J=A \cdot B-C^{2} .
$$

We find derivatives of the second order in the stationary point $M\left(\bar{x}_{o}, \bar{y}_{o}\right)$ and determine its character:

$$
\begin{gathered}
A=\frac{\partial^{2} \bar{V}}{\partial \bar{x}^{-2}}=\left(-152.82-11.24 \bar{y}_{o}+267.84 \bar{y}_{o}^{2}\right) \cdot 10^{-3}=-0.147 \\
B=\frac{\partial^{2} \bar{V}}{\partial \bar{y}^{-2}}=\left(-70.56-319.36 \bar{x}_{o}+267.84 \bar{x}_{o}^{2}\right) \cdot 10^{-3}=-0.166 \\
C=\frac{\partial^{2} \bar{V}}{\partial \bar{x} y}=\frac{\partial^{2} \bar{V}}{\partial \bar{y} \bar{x}}=\left(13.46-319.36 \bar{y}_{o}-11.24 \bar{x}_{o}+535.68 \bar{x}_{o} \bar{y}_{o}\right) \cdot 10^{-3}=-0.006
\end{gathered}
$$

In this case, Jacobian is:

$$
J=A B-C^{2}=(-0.147 \cdot(-0.166))-(-0.006)^{2}>0 .
$$

Taking into account that $J>0$, and $A=-0.147$ that is $<0$, we will state that the function $\bar{V}=f(\bar{x}, \bar{y})$ has a maximum: $V_{\max }(0.585 ; 0.165)=0.057$. From this condition, we determine the initial velocity $V_{o}=V_{r} / \bar{V}_{\max }$, where velocity $V_{r}$ is standardized for the serviced zone as $V_{n}$. This means that the specified initial velocity $V_{o}$ is minimal, that is this value is optimized.

\section{Conclusions}

On the basis of the obtained results we state:

- the quantitative description of the characteristics and regularities of the development of the swirl and flat flooring compressed jets in the reverse flow is established;

- calculation dependences were obtained for determining the parameters of the swirl and flat floor compressed jets in the reverse flow;

- it is substantiated that the efficiency of the application of the swirl and flat flooring jets to supply air to the working area of the technological premises is high. 
The obtained results allow us to calculate the initial velocity of the swirl and tidal flat floor compressed stream in a small-sized production rooms with the presence of technological equipment and service personnel and to determine the geometric parameters of the air distribution device. Application of air distribution with the use of the swirl and flat air jet laying effect allows to significantly increase the ADPI (Air Distribution Performance Index) criteria when supplying a big amount of air to the technological premises and there by reducing the material consumption of the ventilation system.

\section{References}

Bin Zhao, Xianting Li, \& Qisen Yanb Zhao. (2003). A simplified system for indoor airflow simulation. Building and Environment, Vol. 38, 543-552.

Chen, Q., \& Srebric, J. (2001). Simplified diffuser boundary conditions for numerical room airflow models. Final Report for ASHRAE RP-1009, Department of Architecture, Massachusetts Institute of Technology, Cambridge, MA, $181 \mathrm{p}$.

Holyoake. (2006). Diffuser Performance Data Sheet, Ceiling Fixed Pattern Radial Swirl Diffuser, Model CFP Radial Induction Swirl Diffuser.

Kapalo, P., Domnita, F., Bacotiu, C., \& Podolak, M. (2018). The influence of occupants' body mass on carbon dioxide mass flow rate inside a university classroom - case study. International Journal of Environmental Health Research. Vol. 28, No.4, 432-447. ISSN 0960-3123. doi:10.1080/09603123.2018.1483010.

Kapalo, P., Meciarova, L., Vilcekova, S., Burdova, E., Domnita, F., Bacotiu, \& C. Peterfi, K. (2019). Investigation of $\mathrm{CO}_{2}$ production depending on physical activity of students. International Journal of Environmental Health Research. Vol. 29, Issue 1, 31-44. ISSN: 09603123. doi:10.1080/09603123.2018.1506570.

Kapalo, P., \& Siroczki, P. (2014). Calculating the intensity of ventilation in classrooms on the basis of measured concentrations of carbon dioxide in Slovakia - case study. International Journal of Ventilation. Vol. 13, No.3, 247-257. ISSN 1473-3315. WOS: 000348585900004.

Kapalo, P., Voznyak, O., Yurkevych, Yu., Myroniuk, Kh., \& Sukholova, I. (2018). Ensuring comfort microclimate in the classrooms under condition of the required air exchange, Eastern European Journal of Enterprise Technologies, Vol 5/10 (95), 6-14.

Kapalo, P., Vilcekova, S., \& Voznyak, O. (2014). Using experimental measurements the concentrations of carbon dioxide for determining the intensity of ventilation in the rooms, Chemical Engineering Transactions, Vol. 39, 1789-1794. ISBN 978-88-95608-30-3; ISSN 2283-9216.

Kapalo, P., Vilceková, S., Domnita, F., Bacotiu, C., \& Voznyak, O. (2017). Determining the Ventilation Rate inside an Apartment House on the Basis of Measured Carbon Dioxide Concentrations - Case Study, The 10th International Conference on Environmental Engineering, Vilnius, Lithuania, Selected Papers, 30-35.

Srebric, J., \& Chen, Q. (2002). Simplified Numerical Models for Complex Air Supply Diffusers. HVAC\&R Research 8(3), 277-294.

Voznyak, O., Korbut, V., Davydenko, B., \& Sukholova, I. (2019). Air distribution efficiency in a room by a two-flow device, Proceedings of CEE, Advances in Resourse-saving Technologies and Materials in Civil and Environmental Engineering, Springer, Vol 47, 526-533.

Grimitlin, M.I. (2004). Air distribution in the rooms. Issue 3, adapted and supplemented, Moscow: AVOK North-West (in Russian)..

Gumen, O. M., Dovhaliuk, V. B., \& Mileikovskyi, V. O. (2016). Determination of the intensity of turbulence of streams with large-scale vortices on the basis of geometric and kinematic analysis of macrostructure. Proc. of Lviv Polytechnic National University: The theory and building practice, No.844, 76-83 (in Ukrainian).

Dovhaliuk, V.B., \& Mileikovskyi, V.O. (2007). Efficiency of organization of air exchange in heat-stressed premises in compressed conditions, Journal: Building of Ukraine, No.3, 36. (in Ukrainian).

Dovhaliuk, V.B., \& Mileikovskyi, V.O. (2008). Estimated model of non-isothermal stream, which is laid out on a convex cylindrical surface. Ventilation, Illumination and Heat and Gas Supply: Scientific and Technical Collection, Issue 12, Kyiv, KNUBA, 11-32 (in Ukrainian).

Dovhaliuk V. B., \& Mileikovskyi V. O. (2013). Analytical studies of the macrostructure of jet currents for calculating energy-efficient systems of air distribution. Energy efficiency in construction and architecture, Issue 4, 11-32 (in Ukrainian). 
Voznyak, O., Myroniuk, K., \& Dovbush, O. (2005). Relationship between a Person Heat Exchange and Indoor Climate. Selected scientific Papers 10th Rzeszow-Lviv-Kosice Conference 2005 Supplementary Issue. Technical University of Kosice. 148-152.

О. Т. Возняк ${ }^{1}$, М. Адамскі ${ }^{2}$, П. Капало ${ }^{3}$, О. М. Довбуш ${ }^{1}$, І. С. Сухолова ${ }^{1}$

${ }^{1}$ Національний університет “Львівська політехніка”, (м. Львів, Україна), кафедра теплогазопостачання і вентиляції

2 Політехніка Бялостоцька, (м. Бялисток, Республіка Польща), кафедра опалення і вентиляції

${ }^{3}$ Кошицький технічний університет, (м. Кошице, Словаччина), факультет будівництва та інженерії довкілля

\section{ДОСЛІДЖЕННЯ ЗВОРОТНОГО ПОТОКУ \\ ПРИ ПОДАЧІ ПОВІТРЯ ЗАКРУЧЕНИМИ ТА ПЛОСКИМИ НАСТИЛЬНИМИ СТРУМИНАМИ В ПРИМЩЩЕНЯХ НЕВЕЛИКОГО ОБ'СМУ}

(С) Возняк О. Т., Адамскі М., Капало П., Довбуши О. М., Сухолова І. С., 2020

Наведено результати експериментальних досліджень зворотного потоку при розподілі повітря плоскими струменями. Наведено графічні та аналітичні залежності. Результатами досліджень доказано високу ефективність запропонованої схеми розподілу повітря в технологічних малогабаритних приміщеннях. Метою роботи $є$ вивчення характеру розповсюдження вихрових та настильних струменів у обмеженому просторі виробничого приміщення малої висоти 3 наявністю в ньому технологічного обладнання та обслуговуючого персоналу, виявлення закономірностей розвитку повітряного припливного струменя у зворотному потоці та обгрунтування методики розрахунку. Встановлено кількісний опис характеристик та закономірностей розвитку вихрових та плоских настильних стиснених струменів у зворотному потоці. Отримано розрахункові залежності для визначення параметрів вихрових та настильних плоских струменів у зворотному потоці. Обгрунтовано, що ефективність застосування вихрових та плоских настильних струменів для подачі повітря в робочу зону технологічних приміщень є високою. Отримані результати дають змогу обчислити початкову швидкість стисненого потоку вихрового та припливного плоских настильних струменів у невеликих за розмірами виробничих приміщеннях 3 наявністю технологічного обладнання та обслуговуючого персоналу та визначити геометричні параметри пристрою розподілу повітря. Застосування розподілу повітря за ефектом настилання вихрових та плоских повітряних струменів дозволяє значно підвищити критерії продуктивності розподілу повітря при подачі великої кількості повітря до технологічних приміщень і тим самим зменшити витрату матеріалів у вентиляційній системі.

Ключові слова: повітророзподіл, вентиляція, витрата, швидкість повітря, вихровий повітряний потік, стиснений струмінь, настильний плоский повітряний струмінь. 